\title{
EVALUASI PASKA GUNA DENGAN PENEKANAN PADA ASPEK FUNGSIONAL EVAKUASI DARURAT
}

\author{
Forest Jieprang \\ Magister Arsitektur, Program Pascasarjana, Universitas Katolik Parahyangan, Bandung, Indonesia \\ Email: forest@penta.co.id
}

\begin{abstract}
Abstrak
Evaluasi paska guna merupakan salah satu alat untuk mengukur kualitas sebuah bangunan ketika bangunan tersebut telah digunakan. Evaluasi ini digunakan untuk meningkatkan kualitas sebuah bangunan dari segi yang tidak dapat dilihat ketika proses perencanaan berlangsung. Terdapat berbagai aspek yang sering dievaluasi dalam proses evaluasi paska guna. Namun aspek yang sering dijadikan objek evaluasi yaitu aspek teknis, aspek fungsional dan aspek perilaku. Penelitian ini menekankan pada aspek fungsional dengan tujuan untuk mencari permasalahan dari segi evakuasi darurat Stadion Si Jalak Harupat dengan membandingkan objek pengamatan dengan pengalaman pengguna dalam mengenali dan menyadari elemen evakuasi darurat. Pengalaman pengguna akan diambil menggunakan kuesioner dan mental maping, dan respondennya adalah para suporter PERSIB yang menonton di Stadion Si Jalak Harupat. Kedua alat ini akan menggambarkan persepsi dan pengetahuan penonton mengenai legibilitas (keterbacaan) elemen evakuasi darurat pada Stadion Si Jalak Harupat. Kesimpulan yang diambil dari penelitian ini menjelaskan sejauh mana elemen-elemen evakuasi di dalam Stadion Si Jalak Harupat diketahui oleh pengguna dan mencari solusi untuk meningkatkan kesadaran pengguna terhadap elemen-elemen evakuasi darurat di dalam stadion.
\end{abstract}

Kata kunci: Evaluasi paska guna, aspek fungsional evakuasi darurat, stadion Si Jalak Harupat, legibilitas, mental mapping.

\begin{abstract}
Title: Post Occupancy Evaluation for Functional Aspects with Emphasis on Emergency Evacuation

Post occupancy evaluation is a tool to measure the qualities of an in-use building with the purpose of increasing the qualities of the building from the perspective which design process could overlook. There is a lot of aspects that has to be evaluated in the post occupancy evaluation, but the most frequently evaluated aspects are technical aspects, functional aspects, and behavioral aspects. This research emphasizes on the functional aspect to search for problems concerning evacuation circulation of Si Jalak Harupat Stadium by comparing observed object with the experience of users in how they recognize and aware of emergency evacuation elements. Users experience will be collected by using questionnaire and mental mapping. The respondents are Persib supporters who watch the matches at Si Jalak Harupat Stadium. Both of the tools will describe user perception and knowledge regarding evacuation elements legibility. This research will be concluded by describing just how far the evacuation elements of Si Jalak Harupat Stadium known by the users and find the solution to increase users awareness regarding evacuation elements inside the stadium.
\end{abstract}

Keywords: Evaluation of post-use, functional aspects of emergency evacuation, si Jalak Harupat stadium, legibilitas, mental mapping. 


\section{Pendahuluan}

Stadion merupakan bangunan untuk kegiatan olahraga termasuk fasilitas untuk menonton baik pertandingan tingkat daerah, nasional, atau internasioanal, maupun untuk latihan. Tipologi bangunan stadion sepak bola diklasifikasikan berdasarkan besarnya kapasitas penonton, yakni stadion tipe A (kapasitas penonton 30.000 50.000), stadion tipe B (kapasitas penonton 10.000 - 50.000), dan stadion tipe C (kapasitas penonton 5000 10.000). Perencanaan stadion sepak bola dengan standar nasional dan internasional harus merujuk pada Peraturan Menteri Pemuda dan Olahraga (Permenpora) Republik Indonesia Nomor 0400 Tahun 2013 tentang Stadion Atletik dan Sepakbola dan FIFA Football Stadiums: Technical Recommendations and Requirements.

Di Provinsi Jawa Barat terdapat beberapa bangunan stadion sepak bola tipe A, yakni Stadion Si Jalak Harupat (Kabupaten Bandung), Stadion Gelora Bandung Lautan Api (Kota Bandung), Stadion Patriot (Kota Bekasi), Stadion Wibawa Mukti (Kabupaten Bekasi), Stadion Pakansari Cibinong (Kabupaten Bogor).

Penggunaan stadion, sesuai fungsi utamanya, lebih banyak dipergunakan untuk menyelenggarakan pertandingan sepakbola. Masyarakat Indonesia termasuk masyarakat yang memiliki ketertarikan yang sangat besar terhadap olahraga sepakbola. Salah satu fenomena fanatisme penonton klub sepakbola yang sangat menonjol terlihat di Kota Bandung, yang memiliki klub sepakbola Persib Bandung. Klub sepakbola ini selalu mengundang daya tarik bagi masyarakat Jawa Barat. Hal ini dapat dilihat dengan selalu penuhnya stadion yang menjadi arena pertandingan Persib.

Saat pertandingan sepak bola berlangsung, stadion dapat menampung puluhan ribu orang sekaligus $(30.000-50.000$ penonton) dengan waktu penggunaan sangat singkat (2 - 4 jam saja). Dengan kondisi tersebut, masalah evakuasi menjadi penting karena harus mengevakuasi keluar stadion 30.000 50.000 penonton dalam waktu singkat (menurut Permenpora 0400 tahun 2013, waktu untuk evakuasi darurat adalah tidak lebih dari delapan menit). Berbagai kejadian darurat di dalam stadion telah terjadi di berbagai belahan dunia, salah satunya adalah kebakaran di Stadion Bradford City, Yorkshire Barat, Inggris, pada tahun 1985. Kebakaran ini terjadi pada salah satu tribun stadion dan menyebabkan 56 orang meninggal dunia. Terjadi kepanikan dan kebingunan diantara penonton saat dilakukannya evakuasi. Peristiwa lain terjadi di Stadion Heysel di Kota Brussels, Belgia. Peristiwa yang disebut sebagai "Tragedi Heysel" ini terjadi pada tanggal 29 Mei 1985 pada saat pertandingan antara Liverpool dan Juventus di Piala Champions. Penonton yang tidak dapat melarikan diri melalui jalur evakuasi mendekati dinding pembatas dan menyebabkan dinding roboh. Ratusan orang tertimpa dinding yang berjatuhan. Akibat peristiwa ini sebanyak 39 orang meninggal dunia dan 600 lebih lainnya luka-luka. Pada tanggal 12 Maret 1988 tragedi di dalam stadion terjadi pula di Negara Nepal, tragedi ini terjadi saat penonton melarikan diri akibat akibat badai hujan es. Terjadi kepanikan saat para penonton hendak keluar dari stadion yang menyediakan delapan pintu keluar, hanya satu pintu saja yang terbuka. Akibat tragedi ini 93 orang 
menjadi korban jiwa dan dua diantaranya adalah anggota kepolisian, sedangkan 100 orang lebih menderita luka-luka.

Dengan berbagai kejadian darurat yang terjadi di dalam stadion, kita perlu memastikan sistem evakuasi darurat dapat bekerja dengan baik. Untuk mengetahui bekerjanya sistem evakuasi darurat dari sebuah stadion maka perlu dilakukan sebuah Evaluasi Paska Guna atas elemen-elemen evakuasi darurat dan proses evakuasi darurat yang terdapat pada stadion tersebut. Evaluasi Paska Guna adalah proses mengevaluasi bangunan secara sistematik dan teliti setelah bangunan tersebut dibangun dan digunakan dalam beberapa waktu. Fokus dari Evaluasi Paska Guna adalah pengguna bangunan ${ }^{\mathrm{i}}$. Pengguna memiliki peran sebagai penentu atau penilai apakah bangunan yang mereka gunakan bekerja dengan baik atau tidak. Salah satu aspek yang erat dengan pengguna adalah aspek fungsional. Aspek fungsional yang sangat erat kaitannya dengan stadion, karena menampung pengguna dalam jumlah besar dan waktu singkat adalah aspek evakuasi darurat, saat kejadian bencana terjadi.

Lebih lanjut lagi, menurut Heru Susetyo (2015), dosen peneliti Universitas Indonesia, masyarakat Indonesia masih belum memiliki budaya siaga bencana. Kesadaran akan siaga bencana khsusunya atas kehadiran elemen-elemen evakuasi dan legibilitasnya belum secara aktif diperhatikan oleh masyarakat Indonesia ${ }^{\text {ii }}$ Dengan demikian, legibilitas (keterbacaan) dari elemenelemen evakuasi dan proses evakuasi yang ada di benak pengguna stadion (30.000 - 50.000 penonton) perlu dievaluasi melalui Evaluasi Paska Guna Fungsional Evakuasi Darurat.
Mengingat pengguna stadion yang akan diteliti adalah penonton, maka pengambilan data untuk evaluasi harus dilakukan melalui kuesioner, baik kuantitatif melalui data terukur maupun kualitatif melalui wawancara mental mapping. Hasil Evaluasi Paska Guna Fungsional Evakuasi Darurat adalah tingkat legibilitas elemenelemen evakuasi dan pengetahuan akan fase-fase proses evakuasi darurat yang ada di dalam benak penonton.

\section{Metode Penelitian}

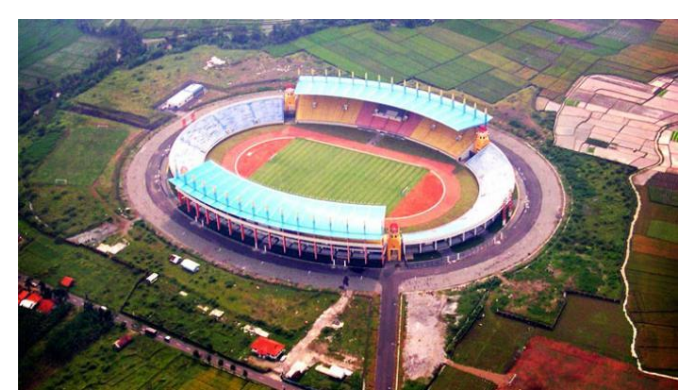

Gambar 1. Aerial view stadion Si Jalak Harupat

Sumber:

http://22koleksi.blogspot.co.id/2015/09/carake-stadion-si-jalak-harupat-bandung.html

Perlunya Evaluasi Paska Guna Fungsional Evakuasi Darurat pada bangunan Stadion Sepakbola dikarenakan banyaknya pengguna stadion (30.000 - 50.000 penonton), apabila terjadi keadaan darurat bencana, maka seluruh penonton harus dapat dievakuasi dalam waktu singkat kurang dari delapan menit sesuai dengan Permenpora 0400. Evaluasi Paska Guna Evakuasi Darurat ini sangat penting karena budaya siaga bencana dari rakyat Indonesia pada umumnya masih sangat rendah sehingga Evaluasi Paska Guna Fungsional Evakuasi Darurat pada stadion diharapkan dapat memberikan rekomendasi perbaikan pada legibilitas elemen evakuasi darurat dan 
percepatan proses evakuasi darurat. Mengingat pengguna yang menjadi fokus penelitian ini adalah penonton, maka pengumpulan data dilakukan melalui kuesioner dengan responden para penonton.

Terkait dengan kasus studi stadion yang dapat menampung 30.000 50.000 penonton pada waktu yang relatif singkat (2-4 jam saja), ruang lingkup dalam penelitian ini dibatasi pada evaluasi paska guna pada aspek fungsional evakuasi darurat. Dalam kaitannya dengan objek penelitian maka evaluasi paska guna fungsional evakuasi darurat ini dibatasi pada penonton stadion saja. Legibilitas elemen evakuasi darurat dan proses evakuasi penonton merupakan produk dari mental seseorang yang dimana produk tersebut akan berbeda setiap orangnya. Meskipun legibilitas elemen evakuasi darurat dan proses evakuasi darurat berbeda setiap orangnya, terdapat pola-pola yang dapat ditemukan kemiripan atau kesamaannya.
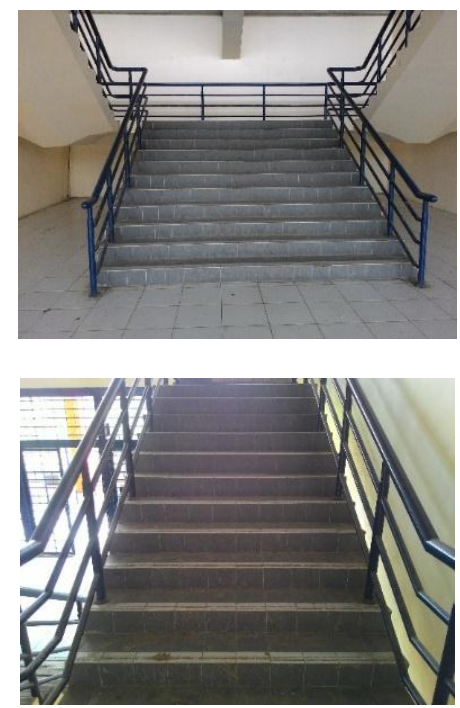
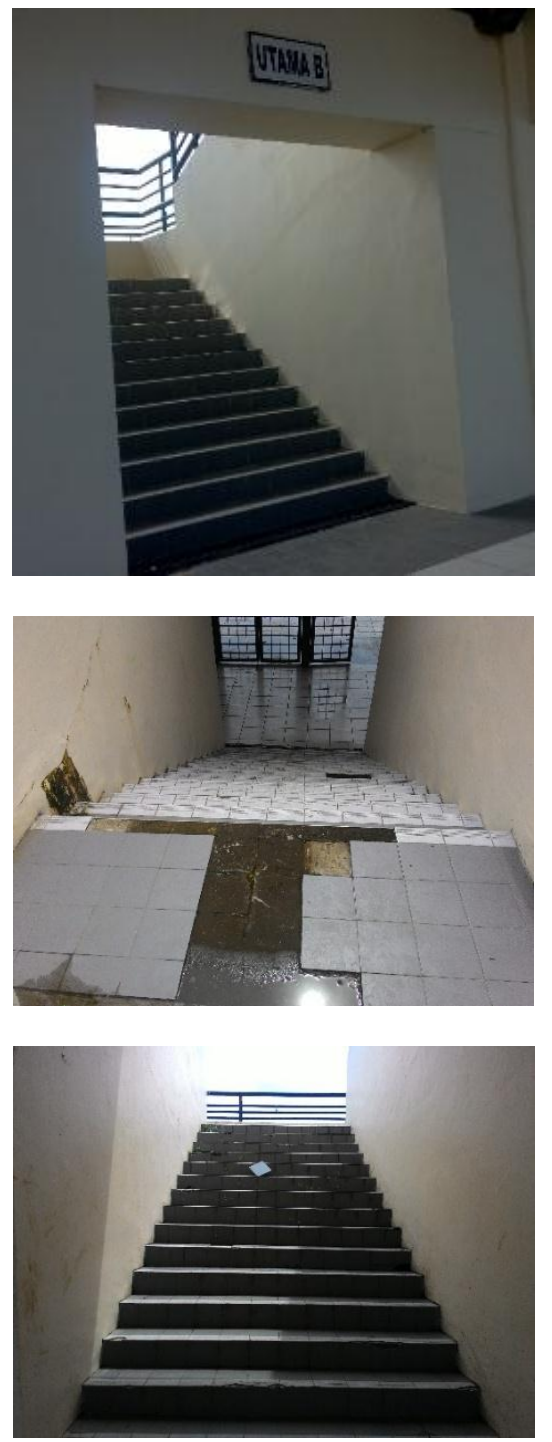

Gambar 2. Beberapa gambar tangga yang ada di tribun utara dan selatan stadion $\mathrm{Si}$ Jalan Harupat

Sumber: Dokumentasi Penulis, 2015

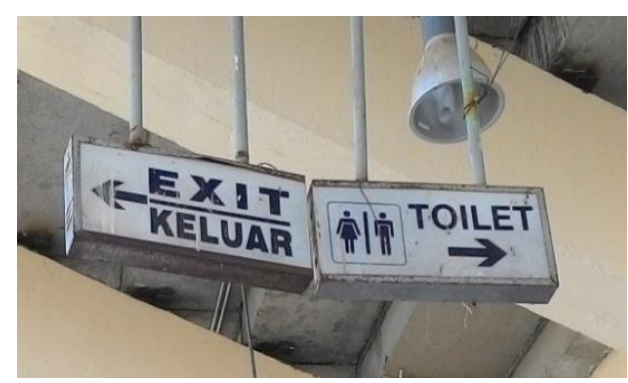




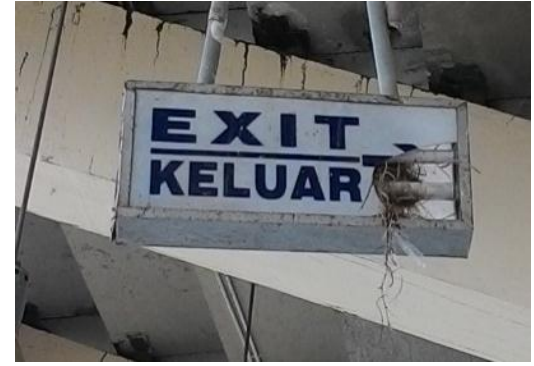

Gambar 3. Beberapa gambar rambu darurat yang ada di stadion Si Jalan Harupat

Sumber: Dokumentasi Penulis, 2016

Untuk mengetahui pola-pola dalam mental seseorang, metode pengumpulan data yang digunakan adalah kuesioner dan mental mapping. Metode pengumpulan data ini penting untuk dilakukan karena metode ini (kuesioner dan mental mapping) dapat langsung mengumpulkan data dari mental seseorang yang tidak ada orang lain selain responden yang dituju yang mengetahuinya. Dengan kata lain data yang dikumpulkan merupakan data yang spesifik. Hal ini yang menjadi pertimbangan pemilihan metode pengmumpulan data menggunakan kuesioner maupun mental mapping.

Selain itu, batasan penelitian ini karena tidak mungkinnya melakukan simulasi evakuasi secara langsung di stadion sepak bola terkait legibilitas elemen evakuasi dan proses evakuasi, merupakan alasan lain mengapa kuesioner dan mental mapping menjadi sangat penting di dalam penelitian ini. Dengan demikian disusunlah pertanyaan penelitian yang bertujuan untuk mengevaluasi elemen evakuasi dan proses evakuasi darurat yang akan menjadi fokus dalam penelitian ini sebagai berikut:

a. Bagaimana pemahaman terhadap legibilitas (keterbacaan) elemen evakuasi darurat pada Stadion Si Jalak Harupat?

b. Bagaimana hasil mental mapping penonton terhadap proses evakuasi darurat pada Stadion Si Jalak Harupat?

\section{Kajian Teori}

\section{Pengertian Evakuasi Darurat}

Evakuasi darurat adalah pergerakan manusia yang sesegera mungkin atau darurat untuk menjauh dari ancaman atau kejadian berbahaya. Contoh skala kecil dari evakuasi adalah evakuasi dari dalam gedung akibat badai atau kebakaran hingga skala besar yang diakibatkan oleh banjir, pengeboman atau cuaca yang sangat buruk yang melanda di suatu kawasan.

\section{Alasan untuk Melakukan Evakuasi}

Banyak alasan untuk seseorang melakukan evakuasi. Evakuasi dapat dilakukan sebelum, saat sedang berlangsung atau setelah bencana. Alasan-alasan untuk evakuasi adalah sebagai berikut:

1. Bencana alam:

a. Letusan gunung merapi;

b. Badai tropis;

c. Banjir;

d. Gempa bumi;

e. Tsunami;

f. Kebakaran hutan.

2. Kecelakaan industri:
a. Tumpahan zat kimia;

b. Kecelakaan nuklir.

3. Kecelakaan lalu lintas; termasuk kecelakaan kereta dan penerbangan

4. Kebakaran

5. Serangan militer:
a. Pemboman;
b. Serangan teroris;
c. Pertempuran militer

6. Kegagalan struktur

7. Pandemik

\section{Rangkaian Fase Evakuasi}

Evakuasi adalah proses dimana manusia di dalam gedung menyadari 
keadaan darurat dan dimana mereka mengalami beberapa proses mental dan melalukan beberapa tindakan sebelum dan atau ketika sedang bergerak menuju tempat yang aman di dalam atau di luar bangunan. Proses evakuasi memiliki tiga karakterisik yang berdasarkan aktivitas dan fase dasar:

1. Kesadaran akan bahaya akibat stimulus eksternal (masa membenarkan tanda bahaya);

2. Membenarkan dan atau respon terhadap indikator bahaya (masa pengambilan keputusan);

3. Bergerak menuju atau mengungsi ke tempat yang aman (masa pergerakan).

\section{Elemen-elemen Evakuasi Darurat}

Dalam evakuasi darurat terdapat beberapa elemen yang mendukung aktivitas evakuasi darurat. Elemenelemen tersebut adalah jalur keluar dan rambu keamanan.

a. Jalur Keluarii

Jalur keluar merupakan sebuah satu kesatuan sistem dimana terdiri dari beberapa elemen yang bertujuan untuk evakuasi penonton di dalam stadion. Sistem jalur keluar dapat terdiri dari koridor, lorong, tangga, ramp atau berbagai alat untuk keluar. Semua jalan keluar harus dapat dikenali dalam keadaan normal ataupun ketika bencana terjadi.

b. Rambu Keamanan ${ }^{\text {iv }}$

Bagian terpenting dalam sistem komunikasi di dalam gedung adalah rambu yang ukuran, kejelasan, keterbacaan yang baik dan lokasi yang tepat. Rambu ini harus dapat dengan mudah dilihat dan dimengerti dalam kondisi cahaya alami yang buruk dan bila dibutuhkan dapat ditambahkan pencahayaan buatan dan atau material yang digunakan untuk rambu adalah material reflektif. Rambu darurat atau rambu kotak obat berbentuk persegi atau persegi panjang dengan piktogram putih pada latar hijau.

\section{Hasil dan Pembahasan}

\section{Legibilitas Elemen Evakuasi Darurat Menurut Penonton}

Legibilitas sesuai dengan intesitas menonton.

Pada grafik 1 menunjukan responden yang baru pertama kali datang menonton di Stadion Si Jalak Harupat, keduanya tidak mengetahui keberadaan tangga darurat. Dalam hal kemudahan mencari jalur evakuasi darurat dan apakah mereka pernah melihat rambu evakuasi di Stadion Si Jalak Harupat, satu responden menjawab ya dan yang lain tidak.

Responden yang pernah satu hingga tiga kali datang menonton di Stadion $\mathrm{Si}$ Jalak harupat, $100 \%$ tidak mengetahui keberadaan tangga darurat. Dalam hal kemudahan mencari jalur evakuasi darurat, $100 \%$ menjawab sulit untuk mencari jalur evakuasi. Dan dalam hal apakah mereka pernah melihat rambu evakuasi di Stadion Si Jalak Harupat, $82 \%$ responden menjawab belum pernah.

Sembilan belas responden yang lebih dari tiga kali datang menonton di Stadion Si Jalak Harupat, 74\% tidak mengetahui keberadaan tangga darurat. Dalam hal kemudahan mencari jalur evakuasi darurat, $63 \%$ menjawab sulit untuk mencari jalur evakuasi. Dan dalam hal apakah mereka pernah melihat rambu evakuasi di Stadion Si Jalak Harupat, 53\% responden menjawab belum pernah.

Yang terakhir, sebelas responden yang selalu datang menonton di Stadion $\mathrm{Si}$ Jalak harupat, $82 \%$ tidak mengetahui keberadaan tangga darurat. Dalam hal 
kemudahan mencari jalur evakuasi darurat, $64 \%$ menjawab sulit untuk mencari jalur evakuasi. Dan dalam hal apakah mereka pernah melihat rambu evakuasi di Stadion Si Jalak Harupat, $82 \%$ responden menjawab belum pernah.
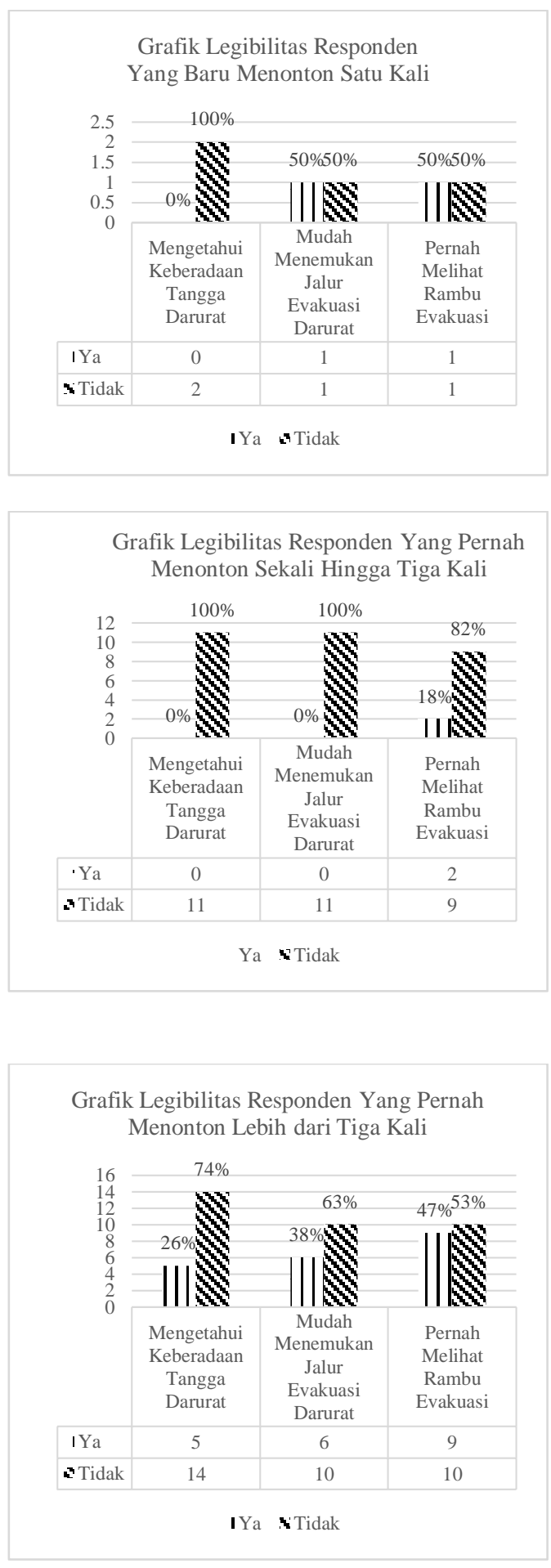

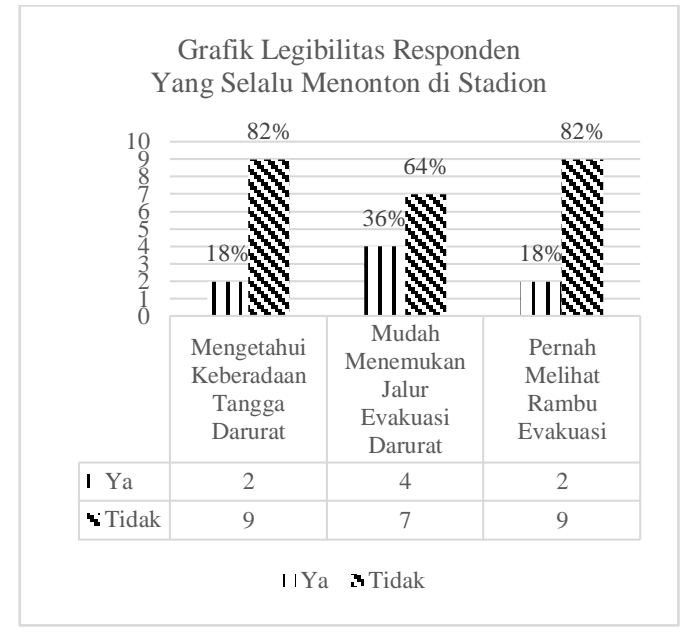

Gambar 4. Grafik legibiltas responden dikelompokkan sesuai intensitas menonton di stadion Si Jalak Harupat

Sumber: Analisa Penulis, 2016

Dari data yang telah disampaikan terlihat bahwa legibilitas elemenelemen evakuasi darurat di Stadion $\mathrm{Si}$ Jalak Harupat menunjukan nilai yang rendah. Atau dengan kata lain, tingkat kesadaran penonton akan adanya elemen-elemen evakuasi darurat (tangga darurat dan rambu evakuasi darurat) terlihat rendah.

Penilaian Legibilitas Elemen Sirkulasi Evakuasi.

Teridentifikasi terdapat indikasi bahwa legibilitas penonton berpengaruh kepada penilaian dari elemen evakuasi yang ada di dalam Stadion Si Jalak Harupat. Pada Grafik 2 menunjukan $53 \%$ orang yang tidak mengetahui keberadaan tangga darurat menilai buruk kemudahan mencari tangga darurat, sehingga dapat diketahui bahwa mayoritas responden tidak mengetahui keberadaan tangga darurat karena tangga darurat tidak mudah untuk ditemukan.

Selain kemudahan mencari, yang mempengaruhi responden untuk mengetahui keberadaan tangga darurat adalah kemudahan untuk mengenali. Pada Grafik 2 menunjukan 57\% orang yang tidak mengetahui keberadaan 
tangga darurat menilai buruk Selanjutnya pada Grafik 2 menunjukan kemudahan untuk mengenali tangga $46 \%$ orang yang tidak melihat rambu darurat, sehingga dapat diketahui bahwa mayoritas responden tidak mengetahui keberadaan tangga darurat karena tangga darurat tidak mudah untuk dikenali. evakuasi menilai buruk kemudahan menemukan rambu evakuasi, sehingga dapat diketahui bahwa mayoritas responden tidak pernah melihat rambu evakuasi karena rambu evakuasi tidak mudah untuk ditemukan.
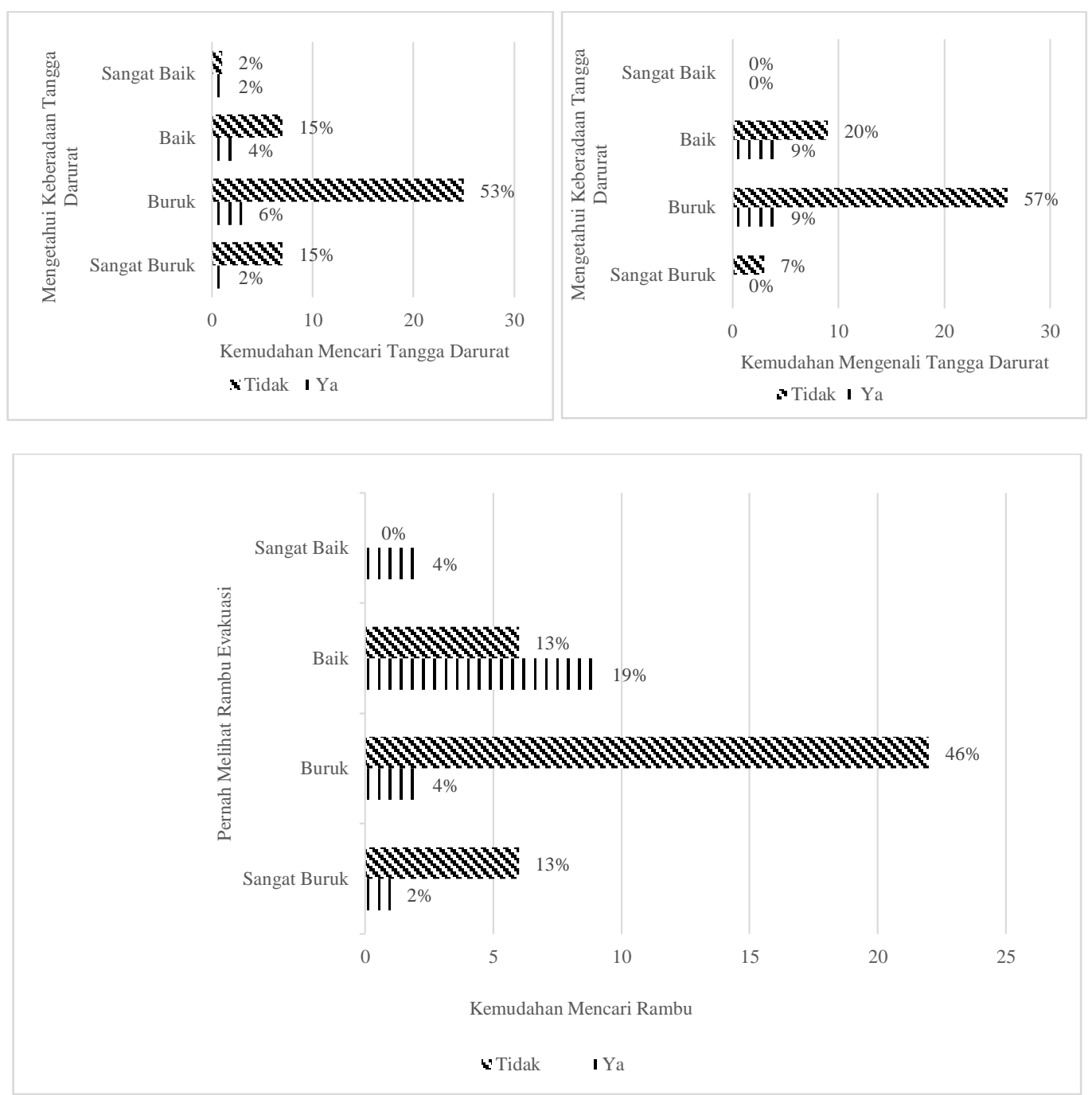

Gambar 5. Grafik koreksi antara mengetahui keberadaan tangga dan pernah melihat rambu dengan kemudahan mencarinya

Sumber: Analisa Penulis, 2016

Face Evakuasi Menurut Penonton

Untuk mengetahui proses evakuasi yang diketahui selama ini oleh penonton, maka data tahapan-tahapan evakuasi diperoleh melalui wawancara mental mapping. Hasilnya kemudian tahapan-tahapan dikelompokan beradasarkan kesesuaian tindakan dalam proses evakuasi. Hal ini dilakukan untuk memudahkan dalam mengelompokan fase evakuasi. 


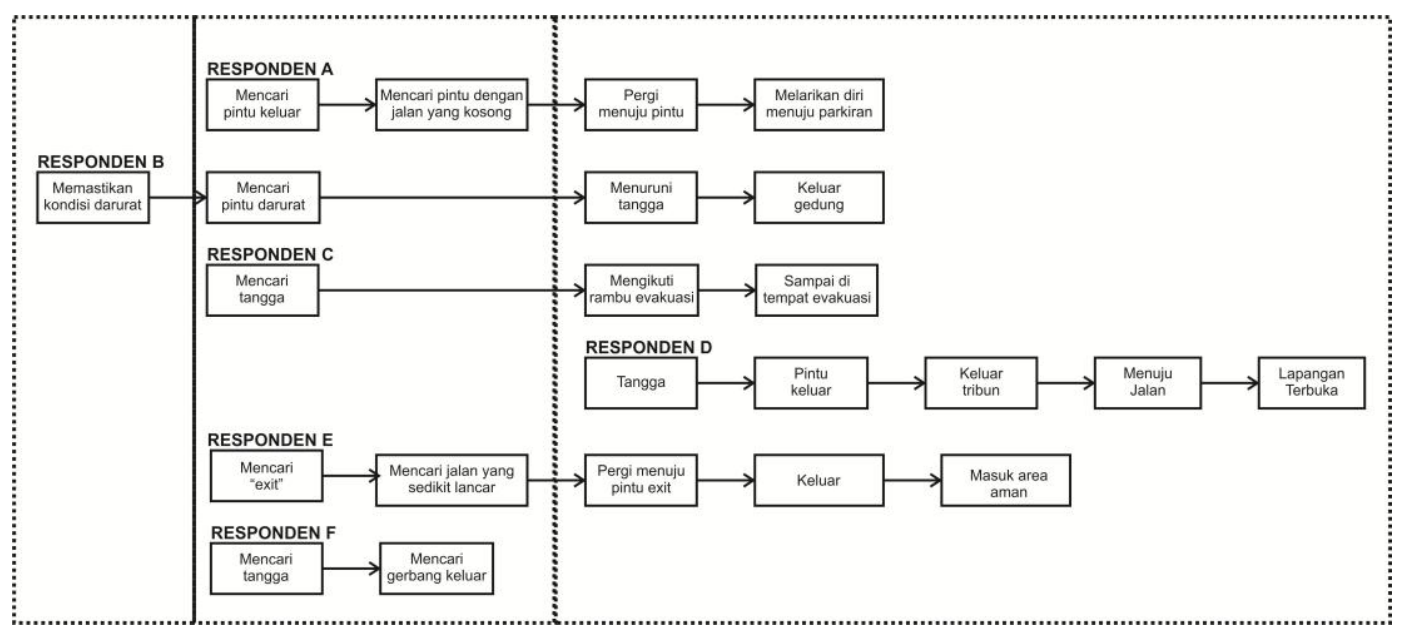

Gambar 6. Diagram pengelompokan face evakuasi responden menurut hasil mental mapping Sumber: Analisa Penulis, 2016

Gambar 6 menunjukan pengelompokan dari tindakan yang dilakukan oleh masing-masing responden sesuai dengan pemahaman mereka dalam mengevakuasi diri. Berikutnya adalah memasukan kelompok-kelompok tersebut kedalam fase-fase evakuasi seperti yang telah diuraikan dalam teori evakuasi sebelumnya. Dengan demikian, dengan melihat gambar 7 kita dapat melihat fase-fase proses evakuasi yang selama ini diketahui oleh penonton.

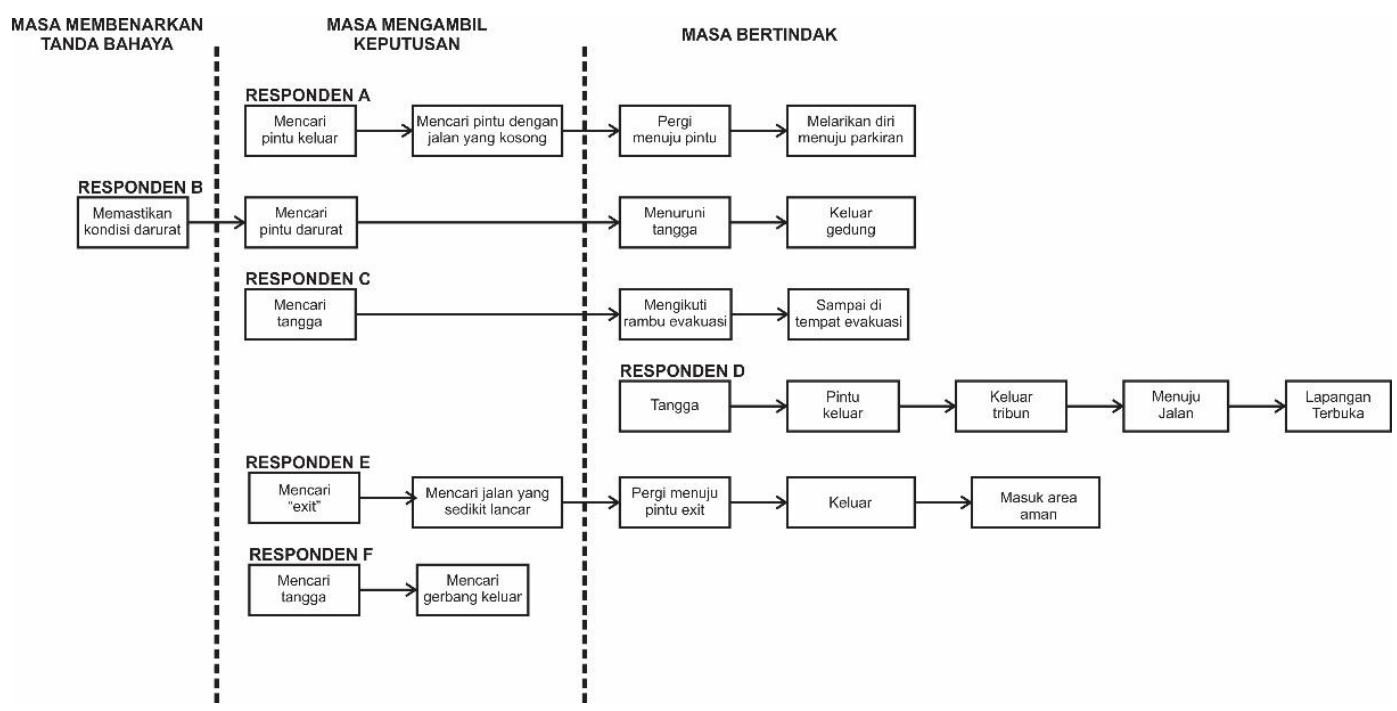

Gambar 7. Diagram pengelompokan proses evakuasi ke dalam face evakuasi sesuai teori evakuasi

Sumber: Analisa Penulis, 2016

Dari seluruh responden, hanya responden $\mathrm{B}$ yang mencari informasi atau mengidentifikasi mengenai kejadian yang terjadi, sedangkan responden lain langsung mengambil keputusan untuk mencari jalan keluar.
Namun pada wawancara, semua responden mencari tahu keadaan dengan bertanya kepada orang lain. Dengan kata lain, responden mengetahui cara mengidentifikasi 
kejadian namun tidak secara sadar untuk melakukannya.

Selanjutnya, semua responden kecuali responden D, melakukan tahapan pengambilan keputusan dimana mereka harus mencari pintu keluar darurat terlebih dahulu sebelum bertindak. Namun berbeda pada hasil wawancara, seluruh responden kecuali responden $\mathrm{E}$ menjawab pertanyaan ke lima dengan mencari jalan keluar atau tempat aman. Dengan ini menandakan bahwa responden belum menyadari lokasi dari tangga darurat evakuasi sebagai jalur evakuasi di dalam Stadion Si Jalak Harupat.

Dan pada tahap bertindak semua orang akan melarikan diri keluar stadion untuk menyelamatkan diri atau menjauhkan diri dari keadaan bahaya. Hanya responden $F$ yang tidak melakukan tindakan menyelamatkan diri. Proses evakuasi yang diketahui penonton secara garis besar langsung berawal dari mencari jalan keluar tanpa mencari tahu keadaan yang sedang terjadi. Hanya responden B yang melakukan tindakan membenarkan keadaan bahaya. Dan bahkan responden D langsung melakukan evakuasi diri tanpa mencari jalan keluar.

\section{Temuan Face Evakuasi untuk Dapat Mempercepat Proses Evakuasi Darurat}

Untuk meningkatkan legibilitas dari elemen evakuasi, kita perlu untuk meningkatkan imageability (kemampuan memberikan citra yang kuat kepada pengamat) dari setiap elemen evakuasi, yaitu tangga darurat dan rambu evakuasi. Untuk meningkatkan imageability elemen evakuasi darurat menurut Kevin Lynch pada imageability-nya adalah dengan memberikan alat-alat simbolik pada elemen evakuasi darurat, melatih ulang penonton, dan mendesain ulang area sekitar elemen-elemen evakuasi darurat. Memberikan elemen evakuasi darurat suatu alat yang dapat menjadi simbol bagi jalur evakuasi darurat tidak dapat dilakukan. Juga untuk memudahkan penonton mengingat lokasi elemen evakuasi darurat, tidak mungkin dengan melatih penonton.

Kedua hal tersebut tidak dapat dilakukan untuk memberikan solusi bagi meningkatkan imageability elemen evakuasi, karena pertama rambu sudah merupakan sebuah alat simbolik yang memudahkan pengguna untuk bergerak dan rambu merupakan elemen sirkulasi evakuasi itu sendiri. Dan yang kedua, melatih penonton bukan merupakan sebuah solusi arsitektural sehingga tidak dapat menjadi solusi di dalam penelitian ini. Dengan demikian, solusi untuk meningkatkan imageability yang terbaik adalah mendesain ulang area sekitar elemen-elemen evakuasi.

Memberikan sebuah alat yang simbolik dapat diterapkan kepada tangga darurat. Hal ini didukung dengan pernyataan dari responden $\mathrm{E}$ yang menyatakan akan lebih mudah mencari tangga darurat bila ada pagar. Responden E mengasosiasikan pagar sebagai sebuah simbol yang dapat melambangkan sebuah lokasi pintu keluar. Tangga darurat memiliki dua alternatif solusi dalam meningkatkan imageability-nya, yang pertama dengan memberikan alat simbolik, dan yang kedua adalah dengan memberikan warna yang menarik perhatian. Untuk meningkatkan legibilitas rambu-rambu darurat, imageability rambu dapat diperkuat dengan membentuk atau mendesain ulang lingkungan sekitar rambu-rambu darurat. Hal ini dikarenakan desain rambu sudah memiliki aturan yang 
ditentukan oleh Green Guide (Guide to Safety at Sports Grounds).

Dengan meningkatkan imageability elemen-elemen evakuasi darurat, implikasi terhadap proses evakuasi adalah mengubah perspektif pengguna terhadap proses evakuasi yang telah mereka ketahui. Responden B mengatakan akan mudah berevakuasi bila telah mengingat lokasi tangga darurat (elemen evakuasi). Dengan demikian perlu ada perubahan tahapan proses evakuasi yang diketahui oleh penonton stadion dan membuat penonton mengingat lokasi tangga darurat sebelum kejadian darurat terjadi. Oleh karena itu, proses evakuasi darurat perlu dievaluasi.

Untuk mengevaluasi proses evakuasi darurat, hal pertama yang dilakukan adalah mengubah fase pada teori (lihat gambar 6) menjadi fase-fase yang lebih mencerminkan hasil mental mapping dan juga untuk memudahkan proses analisis selanjutnya. Terminologi dari setiap tahap kita rubah. Tahap satu dari masa membenarkan tanda bahaya, menjadi mengidentifikasi situasi. Tahap dua dari masa menggambil keputusan dirubah menjadi mencari jalan keluar. Dan tahap tiga dari masa bertindak dirubah menjadi menyelamatkan diri.

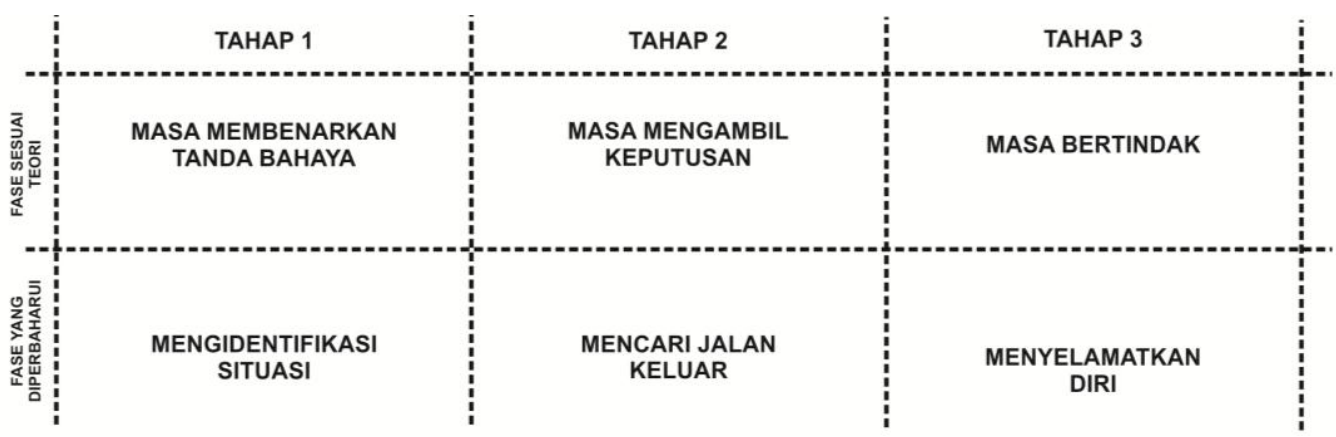

Gambar 8. Diagram perubahan fase evakuasi Sumber: Analisa Penulis, 2016

Untuk membuat penonton mengetahui dan mengingat elemen evakuasi lebih awal, fase lama harus mengalami perubahan dan perlu ada tahapan lain sebelum mengidentifikasi situasi dilakukan. Tahap awal ditambahkan adalah karena untuk membuat penonton mengingat lokasi jalur evakuasi darurat terlebih dahulu, kita perlu membuat penonton mencari jalan keluar sebelumnya. Maka tahap awal ini adalah tahap menemukan lokasi jalan keluar (lihat gambar 9). Lalu, untuk membuat tahap ini berada di awal proses evakuasi adalah dengan membuat denah yang menunjukan jalur evakuasi dan lokasi tangga darurat. Denah ini dibutuhkan untuk membantu penonton mengetahui lokasi jalan keluar dan jalur evakuasi sebelum memasuki stadion. Hal ini dibuktikan dengan jawaban responden $\mathrm{E}$ yang menyebutkan hal yang dicari untuk menemukan lokasi tangga darurat adalah denah evakuasi. 


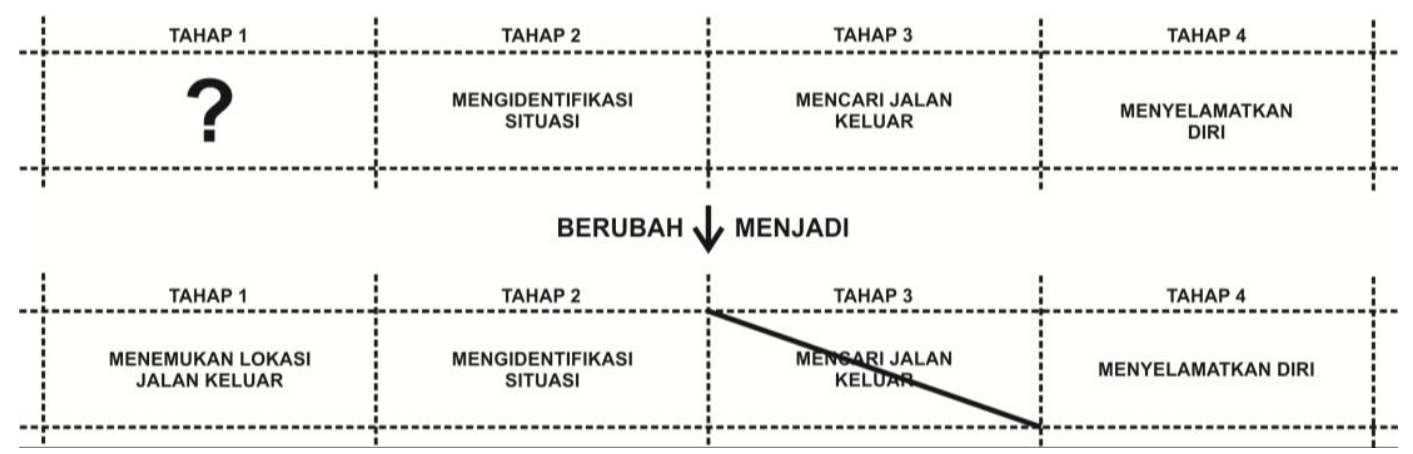

Gambar 9. Perubahan fase dengan meningkatkan legibilitas pada stadion sehingga jalan keluar sudah dapat dipahami sebelumnya

Sumber: Analisa Penulis, 2016

Denah yang menunjukan jalur evakuasi dan lokasi tangga darurat atau denah "Anda Sedang Di sini" (ASD) harus diletakan di setiap titik kumpul penonton stadion terutama di setiap pintu gerbang dan tangga menuju tribun. Dengan demikian ASD akan mudah terlihat dan ditemukan. Keterkaitan antara imageability dengan merubah proses evakuasi adalah upaya peningkatan imageability yang lebih lanjutnya meningkatkan legibilitas pada elemen evakuasi darurat akan membantu penonton untuk melakukan tahap satu di depan, atau menemukan dan mengingat lokasi jalan keluar di depan, saat evakuasi belum terjadi.
Lalu implikasi merubah tahapan yang dilakukan dalam proses evakuasi akan memiliki implikasi terhadap kecepatan proses evakuasi. Sebelum merubah fase mencari jalan keluar, ketiga tahap proses evakuasi berlangsung ketika kejadian darurat sedang terjadi. Setelah fase mencari jalan keluar dirubah, hanya mengidentifikasi jalan keluar dan menyelamatkan diri yang berlangsung ketika kejadian darurat terjadi, dan mencari jalan keluar terjadi ketika kejadian darurat belum terjadi. Dengan demikan proses evakuasi ketika kejadian darurat terjadi menjadi dua tahap saja.

SAAT EVAKUASI

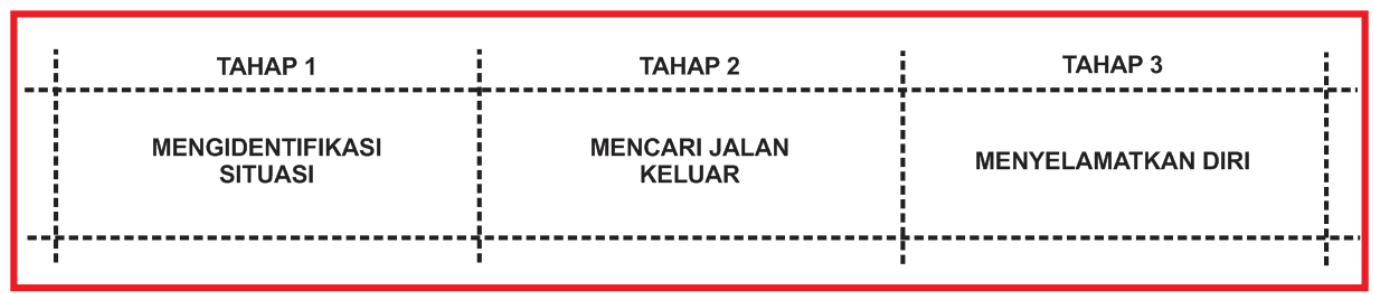

PRA-EVAKUASI SAAT EVAKUASI

TAHAP 1
MENEMUKAN LOKASI
JALAN KELUAR $\quad \begin{gathered}\text { TAHAP 2 } \\ \text { MENGIDENTIFIKASI } \\ \text { SITUASI }\end{gathered}$

Gambar 10. Diagram perbedaan proses evakuasi antara fase teori (atas) dengan fase baru (bawah)

Sumber: Analisa Penulis, 2016 


\section{Rekomendasi untuk Stadion Si Jalak Harupat}

Hasil dari temuan menunjukan, jika elemen evakuasi darurat yaitu tangga darurat dan rambu-rambu evakuasi sulit ditemukan, dikenali dan dibaca, maka legibilitas dari elemen-elemen evakuasi darurat akan rendah. Dengan demikian perlu ada perbaikan untuk meningkatkan legibilitas elemenelemen evakuasi darurat. Perbaikan tersebut adalah dengan meningkatkan kemudahan menemukan dan mengenali tangga darurat dan rambu evakuasi darurat. Desain lingkungan sekitar tangga darurat sedemikian hingga perhatian penonton dapat dengan mudah mengenali dan mengingat tangga darurat dan rambu evakuasi. Selain desain lingkungan sekitar tangga, juga dapat dengan memberikan alat simbolik untuk tangga darurat. Menambahkan denah ASD (anda sedang di sini) di banyak titik untuk memberikan petunjuk kepada penonton mengenai lokasi jalur evakuasi terutama di dekat pintu masuk dan tangga menuju tribun.

\section{Pedoman Perancangan Evakuasi Darurat}

Berikut adalah beberapa temuan yang dapat dijadikan pedoman perencanaan evakuasi darurat bagi stadion sepak bola. Beberapa pedoman tersebut adalah sebagai berikut:

1. Desain lingkungan sekitar tangga darurat dan rambu darurat harus menarik perhatian;

2. Alat simbolik yang dapat mewakili tangga darurat dapat ditambahkan pada desain lingkungan sekitar tangga;

3. Setiap stadion harus memiliki denah yang menunjukan lokasi tangga darurat, pentujuk yang mengarahkan ke luar gedung dan lokasi dari denah itu sendiri (denah ASD).

\section{Kesimpulan}

Pemahaman Penoton Terhadap Elemen Evakuasi Stadion Si Jalak Harupat

Legibilitas elemen evakuasi darurat Stadion $\mathrm{Si}$ Jalak Harupat adalah rendah. Hasil dari kuesioner menunjukan bahwa meskipun penonton sudah datang berkali-kali atau selalu menonton di Stadion Si Jalak Harupat, legibilitas dari elemenelemen evakuasi darurat masih tetap menunjukan nilai yang rendah. Hal ini dipengaruhi oleh buruknya kualitas dari legibilitas elemen-elemen evakuasi darurat Stadion Si Jalak Harupat. Kesulitan mengenali dan mengetahui elemen-elemen evakuasi darurat diakibatkan oleh kualitas yang buruk dari elemen evakuasi darurat itu sendiri. Maka dari itu perlu ada peningkatan kualitas legibilitas dari elemen-elemen evakuasi darurat di Stadion Si Jalak Harupat.

Hasil Mental Mapping Terhadap Proses Evakuasi Darurat

Hasil mental mapping menunjukan persepsi proses evakuasi dari setiap responden yang dikelompokan kedalam fase proses evakuasi. Hasil ini menunjukan fase-fase yang terjadi selama proses evakuasi. Proses ini terdapat tiga tahap dimana tahap satu merupakan tahap mengidentifikasi situasi kejadian, tahap dua merupakan tahap mencari jalan keluar, dan tahap ketiga adalah tahap melarikan diri. Ketiga tahap ini terjadi pada saat kejadian darurat berlangsung, Dengan meningkatkan legibilitas dari elemen-elemen evakuasi dan petunjuk “ASD" (Anda Sedang Di sini), kita dapat mempersingkat tahap-tahap proses evakuasi yang terjadi disaat 
kejadian darurat berlangsung. Sehingga munculnya tahap menemukan jalur evakuasi terjadi ketika keadaan darurat belum terjadi. Dengan munculnya tahap awal ini (pra-evakuasi), tahap mencari jalan keluar dapat dieliminasi, sehingga tahap evakuasi saat kejadian darurat berlangsung hanya tersisa dua tahap saja yaitu tahap mengidentifikasi kejadian dan tahap melarikan diri. Dengan demikian proses evakuasi dapat menjadi lebih cepat.

Dengan meningkatkan legibilitas dari elemen rambu dan tangga darurat, maka penanda "ASD" (Anda Sedang Di sini) menjadi mudah dipahami, diingat dan diikuti, sehingga setelah mengidentifikasi situasi bahaya, proses evakuasi tahap kedua, yaitu menyelamatkan diri dapt berjalan dengan lancar karena elemen evakuasi mudah dikenali dan diikuti arah sirkulasinya.

\section{Daftar Pustaka}

AUDE; Higher Education Founding Council for England. (2006). Guide to Post Occupancy Evaluation England.

Departement for Culture, M. A. (2008). Guide to Safety at Sport Grounds. Green Guide, $5^{\text {th }}$ Edition. TSO.

FIFA. (2011). Football Stadiums, Technical Recomenddation and Requirements. $5^{\text {th }}$ Edition.

Hoski, K. (2004). Fire Protection and Evacuation Procedures of Stadia Venues New Zealand. Master of Engineering in Fire Engineering, University of Cartenbury.

Liu, Y., Liu, D., Badler, N., \& Malkawi, A. (2011). Analysis of Evacuation Performance of Megiing Points in Stadiums based on Crowd Simulation.
Menteri Pekerjaan Umum. (2007). Peraturan Menteri Pekerjaan Umum Nomor 45/PRT/M/2007, Tentang Pedoman Teknis Pembangunan Bangunan Gedung Negara.

Menteri Pemuda dan Olahraga. (2013). Peraturan Menteri Pemuda dan Olahraga Nomor 0400 Tahun 2013, Tentang Standar Nasional Stadion Atletik dan Sepakbola.

Prabowo, H. (n.d). Arsitektur, Psikologi dan Masyarakat. Gunadarma, Jakarta

Preiser, W. F., Rabinowitz, H. Z., \& White, E. T. (1988). PostOccupancy Evaluation. Van Nostrand Reindhold Company Inc, New York.

Snyder, J. C., \& Catanese, A. J. (1997). Pengantar Arsitektur. Erlangga, Jakarta.

Triyosoputri, E. (1992). Evaluasi Purna Pakai Alun-alun Malang dengan Pengekatan Aspek Fungsional. Tesis Magister Arsitektur, Institut Teknologi Bandung.

Yafiz. (1994). Evaluasi Purna Huni Perumahan Nelayan Type Rumah Panggung di Muara Angke Jakarta utara. Tesis Magister Arsitektur, Institut Teknologi Bandung.

${ }^{i}$ Preiser, W. F., Rabinowitz, H. Z., \& White, E. T. (1988). Post-Occupancy Evaluation. New York: Van Nostrand Reindhold Company Inc

${ }^{i i}$ Susetyo, Heru. 20 Maret 2015. Budaya Siaga Bencana. http://staff.ui.ac.id/node/ 47612. Diambil tanggal 27 Juni 2016.

iii Departement for Culture, Media and Sport. (2008). Guide to Safety at Sports Grounds (Green Guide) 5th ed. Hal. 80

iv Ibid. Hal 168 